\title{
How the Scientists Think about Their Reinforcement: A Comparative Study
}

János Szabó (Corresponding author)

Department of Psychiatry and Psychotherapy, University of Pécs, Hungary

Email: szabo.janos@pte.hu

Received: 20/08/2020

Accepted: $15 / 10 / 2020$

Published: 01/11/2020

Volume: 1 Issue: 2

How to cite this paper: Szabó, J. (2020). How the Scientists Think about Their Reinforcement: A Comparative Study. Journal of Practical Studies in Education, 1(2), 16-25 DOI: https://doi.org/10.46809/jpse.v1i2.14

Copyright (C) 2020 by author(s) and Global Talent Academy Ltd. This work is licensed under the Creative Commons Attribution International License (CC BY 4.0).

http://creativecommons.org/licenses/by/4.0/

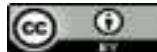

\begin{abstract}
The goal of this study: getting more comprehensive picture about the background of the academic career and about the attitude toward scientific reinforcement. Besides, as another aim is getting insight about: what features of academic career may have cultural aspect and what are universal. With this actually collected sample, consisting of German faculty members/scientist $(\mathrm{N}=40)$, we can see the similarities and the differences between each other (Hungarian) sample $(\mathrm{N}=170)$. The data were collected with questionnaire method (open-ended questions; multiple choices questions; yes/no questions). The earlier Hungarian version consisted of 23 questions, the actual German version contained 28. The questions focused on two main topics: (1) own career of faculty members and (2) identifying of talented students and cooperation with talented students (talented - as a potential scientist). The results have been analyzed with descriptive statistics, correlationexamination, and the open-ended questions had been content-analyzed. They show that the academic career may have cultural differences, but some aspects are universal (independent from country). Of course, the results must be handled as restricted, because other more countries must be investigated.
\end{abstract}

Keywords: Academic Talent, Talented Students, Higher Education, Talent Management, Academic Career

\section{Introduction}

Owing to the Bologna-process (Bachelor, Master; Credit-system), the higher education systems of different nations have become very similar and compatible. But what is after? The doctoral studies, the scientific reinforcement (or in other words: higher education talent management), the structure of academic sphere, the career-path of a scientist: they can be very different among the countries.

It can be handled as an obviously fact: the academic reinforcement (growing up the new generation of scientists) is a very important question for every nation, but the implementation of this can differ. When is it required? During higher education or later? What are the steps of the academic career? How looks out the process during somebody becomes a professor? Similar questions have been taken up in this study and an earlier study serves as a comparative base to this actual study.

The main goal of these studies is to obtain a comprehensive picture about the background of the academic career and the attitude toward the scientific reinforcement. The other goal is to reach empirical evidence, because just the minority of the literature about higher education talent management based on empirical investigations. 
What must be certainly clarified at all the meaning of talent and talent-management in the level of higher education. There are programs (honor-programs), conceptions, colleges who care with the talented students in the aspect of labour market, in business aspect, not necessary as a potential scientist (van Heugten et al. 2017). For example, the Hungarian talent management - at least in higher education level - means the scientific reinforcement: these programs and conceptions are responsible to find and help the students who want to work as a scientist, or a faculty member (Szabó, 2019). In the American (U.S.A.) honor programs (programs for talented students), it can be founded both: scientific reinforcement and gaining advantages for the labour market (Cognard-Black \& Spisak, 2019). The only one common fact is among the studies caring about talent management: talent management means such a program or conceptions which is a supplement of the basecurriculum. Therefore, the talented students are such students whose the basic curriculum is not enough, they want more (Wolfensberger, 2015).

The other question which has emerged when this topic is discussed: Can everybody be a scientist who applies for a scientific-job? In other forms: Can everybody be a professor who goes along the path of the academic career? Should we care about the scientific reinforcement ourselves? Or will the academic labour-market automatically manage the selection later? The answer for these questions is automatically integrated into the higher education system of every nation. That is why the number of talent management programs in higher education is rather independent from the population of a nation, from the number of higher-education institution, from the influence to world-economics, etc.

This comparative study is a continuation of one of an earlier study (Szabó, 2019), where some aspects of the academic career and the scientific reinforcement (growing up the new generation of scientists) had been uncovered. It tries to highlight these differences by taking up some questions about the structure of academic career and about the scientific reinforcement. The first chapter roughs out the background of the scientific mind; how the scientists thinks, works and what attributes they have. After this, I sketch up the opportunities of nurturing talented students who can later work as a scientist. Inasmuch as the sample of this actual study has been collected in Germany, so, as a third step, I summarize the information about the academic career-opportunities in Germany. After that I describe the technical information of the research (sample, method), and finally, I interpret the results in the frame of an earlier study conducted in Hungary.

\section{Scientific Creativity and the Attributes of Scientists}

Scientific creativity means the totality of thoughts and behaviors necessary to advance discipline-specific knowledge (Feist, 2006). As science progresses there needs to be validation from the professional society and through the rigorous process of academic research (theoretical substantiating, hypothesis construction, researching, publication, lecture) (Feist, 2006). This aspect of creativity manifests in the connection of the person, relationships, and their diverse environments. Namely, the researcher investigates and tests and hypothesizes phenomena and relationships of the world. The base of scientific creativity is in many instances an intuitive thought, a supposition, or a moment of coincidence found in unexpected nexuses. It is necessary to mention that this kind of creativity nowadays has become a teamwork approach rather than an individual activity (Feist, 2006).

Feist (2006) has described this construct of scientific creativity, and he has also collected and organized the correlating attributes of the productive scientific career:

- Cognitive traits: open-mindedness, patience, flexibility, psychological mindedness

- Motivation traits: ambition, drive, intrinsic motivation

- Social traits: dominance, arrogance, hostility, introversion, self-confidence.

A scientific career is, partially, measured by performance. This performance revolves around contribution to the scientific community, often through publications. The number of published works correlates with hard work, with competence, with one's professional background, and with a sense of competition. However, if we look at the citation rate, then only hard work and professional background correlate with this rate (Simonton, 2004).

Finally, we must speak about the measurement of the scientific activity. This issue can be approached even from four aspects: from the aspect of the scientific product (the article), from the aspect of the scientists' personalities, from the aspects of creative process, and finally from the aspect of the situation (Stumpf, 1995). The product can be measured on the one hand by the SCI (Science Citation Index - How many times was the article cited). The other way is rating by experts. This measures the quality by similar viewpoints, like novelty, resolution (utility at the problems in the realty), etc. The creative process means those mental steps and activities which are necessary to carry out a research. For example: extended effort, verification, elaboration, etc. These processes can be inspected by introspective reports and they are very variable: which these steps are, which the order of these steps is, they vary at every research and every science area. The creative situation is the summary of those factors which contribute to the scientific creativity. A lot of factors are included into this: the spirit of the times, political- cultural- historical- ideological background, the needs of the society, etc. And finally, from the aspect of the researchers' personalities what is described in the earlier chapters. This part contains the personality traits and cognitive factors which were mentioned above (Stumpf, 1995). And this is the way how I have investigated the talent-factors in this study. 


\section{Higher-Education Talent Management around the World}

Comparing with the gifted education during primary and secondary studies (nurturing and developing intellectually emerging children), the higher-education talent management is an under-investigated area. A lot of study approaches this topic from HR-aspect (Neri \& Wilkins, 2019; Gandy, Harrison \& Gold, 2018; Boichenko, 2015). Among the studies written about talented students, just a few investigate the talented students with empirical methods (Cognard-Black \& Spisak, 2019).

The majority of the conducted empirical studies was conducted in the U.S.A, where $300000-400000$ students participate in honor programs (Cognard-Black \& Spisak, 2019). These honor programs means the talent management during higher-education studies. Although, the conceptions of these programs are different in institutes, universities; there are some common features. For example: the "talented" refers to the academically talented undergraduate students (Cognard-Black \& Spisak, 2019). So, when we read the literature of higher-education talent management, we meet mainly with "honor student" term, instead of talented student. Hence, the honor program is an American conception, it would be not appropriate to use at the case of Hungarian conceptions.

In the aspect of talent-management programs, the European universities are underrepresented, compared to American ones. Much less university has talent program in Europe, and the majority of these are found in the Netherlands (Wolfensberger, 2015). Hence, empirical researches about talented students in higher education are very rare in Europe. The few examples are mainly originated also from the Netherlands (Scager et al., 2012; Hammer, 2015). So, conducting an empirical research, involving talented university students, is a fairly new approach.

There are studies which used psychological questionnaires or scales to measure talented - such students who are involved into honor/talent programs - students in higher education. These studies usually found differences between talented and nontalented students. For example: Talented students are more opened to the experiences and more conscientious than their nontalented peers (Long \& Lange, 2002). An investigation used BIG5 questionnaire which proved that talented students are more conscientious, open, emotionally instable, and introverted (Achtenberg, 2005; Cross et al 2018). Besides psychological features, the GPA, learning strategy (Cuevas, Schreiner, Kim \& Bloom, 2017), and behavioral features are also used methods at investigation of this topic. The GPA is higher at honor students than non-honor mates (Cognard-Black, \& Spisak, 2019), but this does not prove to be true in every case (Shushok, 2006). The most investigated features connect to the living on the campus, free-time, connect with the faculty and faculty member, and participating in activities. The honor students train and sleep more, than their non-honor mates; they consult more with their teachers; they participate more in religious activities, in charity work, and community service (Cognard-Black \& Spisak, 2019).

Another argument of higher-education talent development must be mentioned. Higher education has become a standardized, structured approach of mass education in many countries over the past few decades. This is a shift from what the university was for centuries; a form of gifted education in and of itself (Balogh, 2012). Therefore, talented students must be identified in this mass-education approach and provide them appropriate services. We must pay critical attention to prevent gifted secondary school students from dropping out of their studies, and at the same time, locate new potential scientists among the university students.

\section{Scientific Reinforcement in Germany}

There are more research-institutes in Germany (for example: DZHW - German Centre for Higher Education Research and Science Studies or IHF - Bayerisches Staatsinstitut für Hochschulforschung und Hochschulplanung) what work independently from the universities, and whose goal is improve the higher-education system (quality management, scientific reinforcement, etc.). So they collect samples from more university around the country. In addition, of course, there are universities who have different institute to improving the scientific reinforcement. The easiest way to uncovering the literature is reading the reports of these institutes. In this chapter, I summarize the results of some large-scale research-project conducted by similar institutes.

In these reports, the definition of scientific reinforcement is not clear and refers mainly to the doctoral studies or the postdoctoral phase (Gundlach \& Korff, 2015; Krabel et al 2017). But some reports offers: it should be expanded this notion also to the undergraduate level (Bargel \& Röhl, 2006; Krabel et al 2017). So, the collected sample of these studies consists of doctoral students or postdoc researcher, as career entrants into the scientific career.

These studies report the low rate of women in the academic sphere (Bundesbericht Wissenschaftlicher Nachwuchs, 2017), because Germany has the most shifted balance in Europe on the scale of male-female scientists (Gundlach \& Korff, 2015). The other problems which have emerged at once the determined job-contraction, because only the professors get unlimited job-contraction, the lower ranked scientist have to work with contraction with expiring date. The other problem is the "bottleneck" effect which means: only a few percent of the researches can earn the professorship. Further problem is the compatibility between the family and career. (Bargel \& Röhl, 2006; Gundlach \& Korff, 2015; Krabel et al 2017).

Participating in a doctoral education means not necessarily that a student wants to work later in the science: a lot of lawyer and physician students want to complete a doctoral education for the doctor title (Bargel \& Röhl, 2006). The reasons of doctoral education show this phenomenon: more students marked the reason " $\mathrm{CV}$ improvement" than reason "scientific career" (Krabel et al 2017). Preventing this effect, some country gives automatically the doctor title with the degree. The 
problem with this: it exaggerates the prestige-differences among the professions. Why does some profession merit doctor title already directly after the undergraduate studies, while other students have to complete a doctoral education?

The selection process - choosing the students, who want to apply for doctoral education - is the responsibility of the professors. At applying to doctoral education, there are more important factors (note of Master thesis, quality of research plan, GPA - Grade Point Average), but the most important role seems to the personal impression (Berning \& Falk, 2006).

The subjective factors, what need for academic career, are the following: responsibility; discipline; preparedness; tolerance of frustration; persistence; high work capacity; passion (Gundlach \& Korff, 2015). By an earlier study (Szabó, 2017) the German professors found the following ones as the most important attribute of a potential scientist: selfdependence; professional knowledge, logical thinking, intrinsic (inside) motivations; recognizing the coherency.

\section{Method}

The data were collected with questionnaire method (open-ended questions; multiple choices questions; yes/no questions). The earlier Hungarian version consisted of 23 questions, the actual German version contained 28 (owing to the agreement with professionals, uncovering the German literature, different career-opportunities in the higher education). Obviously, the language of questionnaires fit to the language of the given country. The questions focused on two main topics: (1) own career of faculty members and (2) identifying of talented students and cooperation with talented students. Every question, which measures attitude, was used with a $1-7$ Likert scale. To make the data more interpretable, I attach the actually used questionnaire as Appendix 1.

\section{Sample}

Both samples consisted of faculty members: The actual German sample consisted of faculty members of a German university (University Hildesheim). Although, the questionnaire had been sent out for every faculty members, the response rate was very low: 40 persons have completed the whole questionnaire without leaving out $(\mathrm{N}=40)$.

The Hungarian sample - used in an earlier study (Szabó, 2019) was recruited by the supervision process during the largest Hungarian scientific competition for students (OTDK 2017 - National Scientific Conference for Students - 2017). So, the asked participants were supervisors of academically talented students (students who qualified to OTDK 2017 competition) and they were recruited by the database of OTDK 2017. The only one condition of adding a university-teacher to the recruitment database was: being in the following position: professor, associate professor, assistant professor, researchfellow. The questionnaire has been sent to 722 professors (owing to several "address not found" error messages). 170 answers have come in. In this article, I introduce only the German sample, because the diagrams about the Hungarian one can be seen in the previous study (Szabó, 2019).

In the aspect of science domain, the German sample is also balanced, as the Hungarian one. So, the participants came from every science-domain how Figure 1 shows.

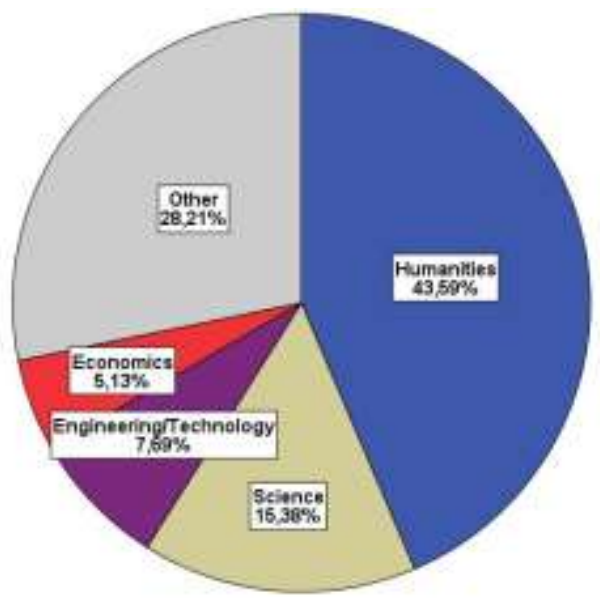

Figure 1. Distribution of science-domains

Figure 2 shows the distribution of the positions according to the answer-givers. 


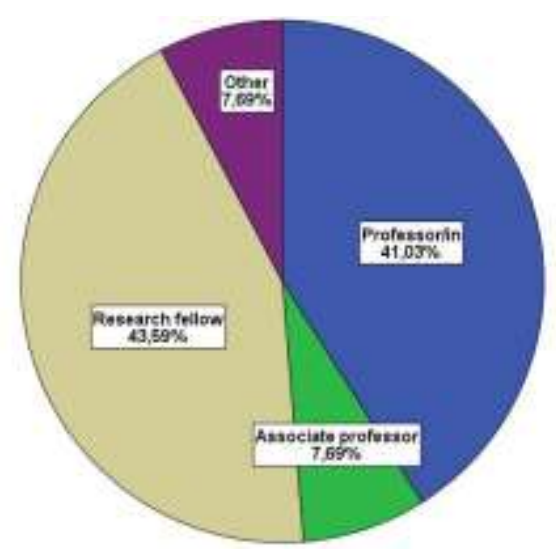

Figure 2. Distribution of positions

The time, which the faculty member spent in the scientific career, is represented on Figure 3.

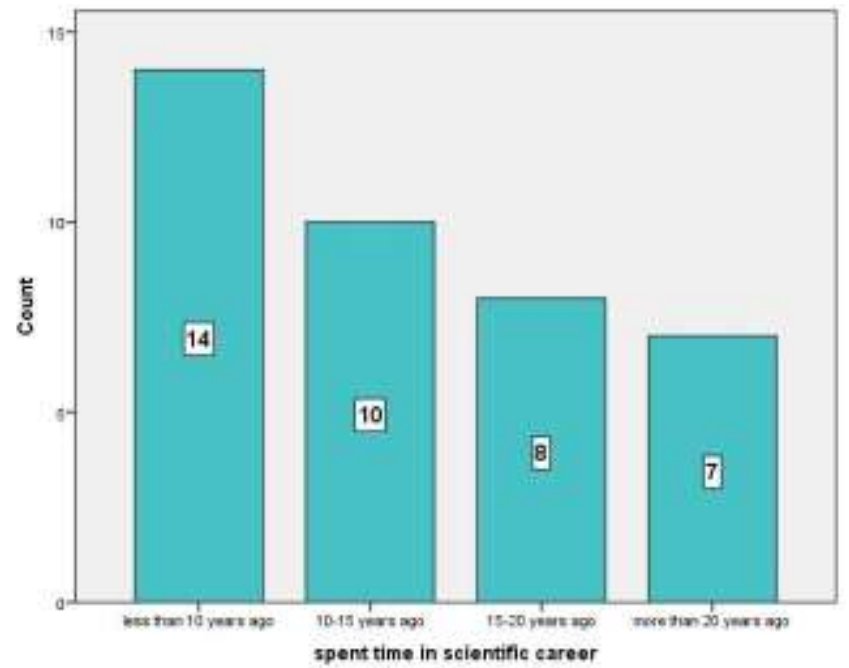

Figure 3. Distribution of faculty members by spent time in scientific career

The "bottleneck" effect, mentioned in the literature, can be seen on the chart, because the more time spends the less faculty member stays in the scientific career.

\section{Results}

Hence, the main purpose of this study was exploration of university-teachers' opinions, the most of questions had been analyzed with descriptive statistic (ranking the mostly chosen answers, frequencies of answers, distributions of available options). Besides, there are some correlation-analyze.

The number of publication (Mean: 43, 19; SD: 58,455) circle for time higher $(4,4 \mathrm{x})$, than the number of rejections, namely the failures (Mean: 9, 83; SD: 22,157). This result is supported by the subjective estimation of the faculty members, too. It is shown by Figure 4 . 


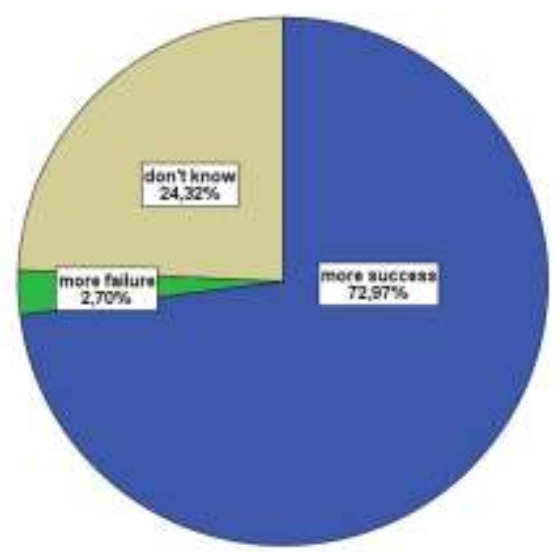

Figure 4. Distribution of subjective estimation of success and failures

Although, the 5,72 mean (SD: 1,276) in a $1-7$ Likers scale is a little bit contradicting with these result, because it means the participants think rather as a necessary part of the academic career.

When the advantages and disadvantages asked, free-answer feld was used, so, into this place could the participants type their own answers. These data was content analyzed by the cathegories of the earlier, Hungarian study (Szabó, 2019). The answers with the number of mentions, written by the faculty members, are contained in Table 1.

Table 1. Mostly mentioned advantages and disadvantages of scientific career

\begin{tabular}{|l|l|}
\hline \multicolumn{1}{|c|}{ Advantages (number of mentions) } & \multicolumn{1}{c|}{ Disadvantages (number of mentions) } \\
\hline Freedom, self-dependence (27) & Uncertainty, limited contractions (28) \\
\hline Epistemic needs (17) & Overcharge (11) \\
\hline Research as a pleasure activity (12) & Stress, pressure (11) \\
\hline Education - working with students (11) & Income (10) \\
\hline Social environment and social connections (10) & Work conditions (6) \\
\hline Variedness (9) & Family - work compatibility (5) \\
\hline Prestige (8) & Competition (5) \\
\hline Development and career opportunities (7) & „Bottleneck“ effect (4) \\
\hline Income (4) & Required mobility (4) \\
\hline Challenges (3) & Administration (3) \\
\hline
\end{tabular}

The participants mentioned a little more advantages (Mean: 3,7; SD: 2,554) than disadvantages (Mean: 2,9; SD: 2,216) The only one scale-type variable, which correlated with the number of advantage-mentions, was the number of publication (corr.: 0,496; $\mathrm{p}=0,002$ ). This means: the more publication somebody has, the more think that the science is a beneficial career. There was not any scale what correlated with number of disadvantage-mentions.

Only $50 \%$ of the participants has marked that he has an exemplar-person. This was $72.9 \%$ in the earlier study.

The most mentioned (26 times) exemplar-person was a university-teacher/a professor. The others were rather less mentioned.

The two third part $(66,67 \%)$ of the participants thought at first time to being a scientists during their university studies. A little part thought to it earlier (before higher education studies - 18,18\%) and another little part later, during doctoral studies $(15,15 \%)$. This result differs from the result of earlier study, where only $37,65 \%$ marked the "during higher education studies" option even though they were also the majority. The possibility of a scientific job during higher education studies was estimated 3,45 (SD: 1,748) in a $1-7$ Likers scale, so, exactly in the middle of possible-impossible. The concreteness of future-plans was 4,00 (SD: 2,032).

$52,5 \%$ of the participants had already worked elsewhere in academic sphere. $62,5 \%$ has already thought about it: to give up the academic career.

The most influential factor (among the personality, cognitive skills, and environmental factors) of the academic career is the personality (Mean: 6,19 SD: 1,117): this was unambiguous higher ranked than the other two, the cognitive skills (Mean: 5,41 SD: 1,417) and the environment (Mean: 5,46; SD: 1,442)

The question, referring to advices for young, career entrant scientist, was also a free-answer question. The majority of the advices (14) referred to considering, weighting the advantages-disadvantages.

The competition in the academic career was estimated rather high (Mean: 6,00; SD: 1,346). Although, attaining this actual position, the rate was lower (Mean: 4, 65; SD: 2,013). 
$55 \%$ of participants declared that "Yes, it can be predicted about a student during his/her higher education studies whether he/she becomes a scientist/a university teacher.". This rate was $74,9 \%$ in the earlier sample.

The mostly marked options to the question: "If yes; what are the indicators during undergraduate studies that somebody prepares to scientific career?" were:

- His/her questions, comments, essays often pertain to other science-domain, to other topic. $-65 \%$. This was chosen by $60,9 \%$ of the Hungarian sample, on the second place.

- He/she puts the balance at his/her essays/papers rather on the quality, than the length of the text. $-50 \%$. This was chosen by $75,5 \%$ of the Hungarian sample, on the first place.

Also, the two samples think similarly in the aspect of this question.

There was not any option to the question "Which methods/information/data can be effective to identify academic undergraduate talents?", which was chosen at least by the third part of the participants. So, this question is not worth to analyze in this study. The only one appraisable option in the Hungarian sample was "Test-tasks, based on practical problems $-52.4 \%$ ", but no more.

The mostly influential factors during an applying process for a doctoral education were the personal talk $(72,5 \%)$ and the CV (60\%) options.

\section{Discussion}

The analyzed data - already in themselves - can come up to useful information for those who interest to this topic. It reaches useful information about the academic career and the starting of the academic career. Table 1 summarizes the most important advantages and disadvantages. The described data is not proper to compare with each other; the most informative parts of them are the percentages.

The attributes and criteria of the potential scientists (talented students) are rather similar, which was proved by an earlier study (Szabó, 2017). The answers overlap with the literature in the aspect of the disadvantages: the mostly answered fact was the uncertainty (limited contractions). The subjective rate of successes-failures and the number of rejections contradict to Selye's (1964) statement, according to a researcher must take account of more failures than successes. It is important to highlight the personality and attitude, which was more importantly estimated than other (cognitive and environmental) factors among participants in both countries.

\section{Conclusion}

The question: "Is it possible to identify during undergraduate studies, which student will be a good scientist?" is a good base of comparative studies among nations. The answer shows how a nation thinks important the higher-education talent management during undergraduate studies. How this study shows, some nations (like Hungary) think more important this process, than other nations (Germany). Of course, this assessment can depend from a lot of other factor (structure of doctoral studies, structure of higher education, etc.). It is obviously, that the scientific reinforcement is a very important question for every nation, but the implementation can differ. For example: when it is required? Already during higher education studies? Or just later? What resources give more information about the expected performance of a potential scientist? The CV? A personal talk? According to this actual and earlier study, the fate of an academic talent is not decided during higher education studies, but it is proved that a lot of scientific career start during higher education studies.

The main limitation of this study is the low number of the participants, and the number of countries (2; Germany and Hungary) where the questionnaire implemented was. Another is: the equality sign between the academic performance and the number of publications. It was the most optimal choice, because the questionnaire had to be short owing to the very few time of university-teachers. Although, unfortunately, there are scholarships/applications/financial research-supports at which the decision-criteria is based on the number of publications.

The results may suggest conceptions for talent-programs (honor programs) based on academic talent; for doctoral schools, and for any other institutes who works with career entrant scientist. The meaning of this study is not showing the differences between two countries, but also an invitation for similar studies. It would be very useful, if we had a resource (even a book, even a webpage) which may help by comparing the academic sphere among different countries. This would be useful such people who are preparing for the academic career.

\section{References}

Balogh, L. (2012). Komplex tehetségfejlesztő programok. Didakt kiadó, Hajdúböszörmény.

Bargel, T, \& Röhl, T. (2006). Wissenschaftlicher Nachwuchs unter den Studierenden: Empirische Expertise auf der Grundlage des Studierendensurveys. Bundesministerium für Bildung und Forschung, Berlin.

Berning, E., \& Falk, S. (2006). Promovieren an den Universitaten in Bayern: Praxis - Modelle - Perspektiven. Bayerisches Staatinstitut für Hochschulforschung und Hochschulplanung, München.

Boichenko, M. (2015). Talent Management Programmes at British, American and Canadian Universities: Comparative Study. Comparative Professional Pedagogy, 5(4). 68-72. DOI: https://doi.org/10.1515/rpp-2015-0068 
Cognard-Black, A. J., \& Spisak, A. L. (2019). Creating a Profile of an Honors Student: A Comparison of Honors and NonHonors Students at Public Research Universities in the United States. Journal of the National Collegiate Honors Council, 20(1). 123-157.

Cross, T. L., Cross, J. R., Mammadov, S., Ward, T. J., Neumeister, K. S., \& Andersen, L. (2018). Psychological heterogeneity among honors college students. Journal for the Education of the Gifted, 41(3), 242-72.

Cuevas, A., Schreiner, L. A., Kim, Y., \& Bloom, J. (2017). Honors student thriving: A model of academic, psychological, and social wellbeing. Journal of the National Collegiate Honors Council, 18(2), 79-119.

Feist, G. J. (2006). The psychology of science and the origins of the scientific mind. New Haven, CT: Yale University Press.

Gandy, R., Harrison, P. \& Gold, J. (2018). Talent Management in Higher Education: Is Turnover Relevant? European Journal of Training and Development, 42 (9), 597-610. DOI: https://doi.org/10.1108/EJTD-11-2017-0099

Gundlach, J. \& Korff, S. (2015). Chance: Postdocs - Chancengleichheit in der Post-Doc-Phase - Gender und Diversity. Stiftung Universität Hildesheim, Hildesheim.

Hammer, M. H. (2015). Towards a Methodology to Identify a Talent by Using Psychological Cognitive Prototyping. Practice and Theory in Systems of Education, 10 (4), 397-409. DOI: https://doi.org/10.1515/ptse-2015-0038

Krabel, S., Winterhager, N., Shajek, A., Lindow, I. \& Birner, N. (2017). Bundesbericht Wissenschaftlicher Nachwuchs 2017. Konsortium Bundesbericht Wissenschaftlicher Nachwuchs. W. Bertelsmann Verlag GmbH \& Co. KG, Bielefeld.

Long, E. C. J. \& Lange, S. (2002). An exploratory study: A comparison of honors \& non-honors students. The National Honors Report, 23 (1), 20-30.

Neri, S. \& Wilkins, S. (2019). Talent Management in Transnational Higher Education: Strategies for Managing Academic Staff at International Branch Campuses. Journal of Higher Education Policy and Management, 41 (1), 52-69. DOI: https://doi.org/10.1080/1360080X.2018.1522713

Scager, K., Akkerman, S. F., Keesen, F., Mainhard, M. T., Pilot, A., \& Wubbels, T. (2012). Do honors students have more potential for excellence in their professional lives? Higher Education, 64, 19-39. DOI: 10.1007/s10734-011-9478-z

Selye, J. (1964). From dream to discovery - On being a scientist. McGraw-Hill, New York.

Shushok, F. (2006). Student outcomes and honors programs: A longitudinal study of 172 honors students 2000-2004. Journal of the National Collegiate Honors Council, 7(2), 85-96.

Simonton, D. K. (2004). Creativity as a Constrained Stochastic Process. In: Sternberg, R. J., Grigorenko, E. R., Singer, J. L. (Ed.): Creativity From Potential to Realization. (pp. 83-102) American Psychological Association. Washington, DC.

Stumpf, H. (1995). Scientific Creativity: A Short Overview. Educational Psychology Review, 7 (3), 225-241.

Szabó J. (2017): A tudományos tehetség legfőbb összetevői a tudósok szempontjából. In: Koncz I., Szova I. (eds): A 15 éves PEME XV. PhD - Konferenciájának elöadásai. Professzorok az Európai Magyarországért Egyesület, Budapest. 130 139.

Szabó, J. (2019): How Can Be Academic Talent Measured During Higher Education Studies? - An Exploratory Study. Higher Education Studies, 9 (4). 200-214. DOI:10.5539/hes.v9n4p200

Van Heugten, P., Heijne-Penninga, M., Robbe, P., Jaarsma, D. \& Wolfensberger, M. (2017). International Perspectives on the Profile of Highly Talented International Business Professionals. Journal of Education for Business, 92(7), 323331.

Wolfensberger, M. (2015). Talent Development in European Higher Education. SpringerOpen, Heidelberg.

\section{Appendix A}

The used questionnaire during the study (English translation)

1. Science-domain

2. Position

3. How long have you been working as a scientist?

$0-5$ years

$6-10$ years

$11-15$ years

$16-20$ years

More than 20 years

4. How many of your scientific paper has been published till now, in total? (Involving articles, book-chapters, monograph, etc.)

5. In total, how many of your paper has been rejected till now, at submitting to a scientific journal?

6. How do you estimate the relation of success and failures during your academic career thus far?

I have more success than failure

I have more failures than success

I cannot decide 
7. How do you think about failures as a part of academic career?

1 - They are not necessary a part of scientific career

7 - Avoidless

8. What are the advantages of scientific career?

9. What are the disadvantages of scientific career?

10. Did you have exemplar-persons/ideals (Vorbilden/ a person who is similar or who has some attributes as your futureimage)?

11. Are there any people (parents, friends, teachers, professors, relatives, etc.), who influenced your choice: working in the academic-sphere?

12. When did the idea emerge in your mind to become a scientist?

13. How fix conceptions did you have during the university studies about the plans after finishing the university?

1 - I had no idea

7 - I had concrete plans

14. Have you ever worked outside of the scientific-sphere?

15. Have you ever thought about giving up the academic career?

16. How possible did it seem working as a scientist during your undergraduate study?

1 - Impossible

7 - Absolutely real

17. According to your opinion, how is the academic career influenced by cognitive skills (e.g. memory, intelligence)?

1 - Unimportant

7 - essential

18. According to your opinion, how is the academic career influenced by personality traits (e.g. persistence, curiosity, diligence)?

1 - Unimportant

7 - essential

19. According to your opinion, how is the academic career influenced by external factors (e.g. opportunities at university, organization of society, social background, luck)?

1 - Unimportant

7 - essential

20. What would you offer for such students who want to be a scientist?

21 . Which is important for you: teaching or researching?

22. According to your opinion, how competitive is the academic sphere?

1 - It is not competitive

7 - There is a heavy concurrence

23. How was it easy to earn this actual position? (It was easy VS I stick it in)

1 - It was easy

7 - I stick it in

24. Is it possible to identify during undergraduate study, which student will be a good scientist?

25. If yes; what are the signs during undergraduate studies that predict whether a student would be a successful researcher?

$\mathrm{He} /$ she visits regularly also lectures, not only obligatory seminars.

$\mathrm{He} / \mathrm{she}$ asks often in class.

$\mathrm{He} /$ she is simply very smart.

$\mathrm{He} / \mathrm{she}$ has creative ideas.

$\mathrm{He} /$ she thinks like a scientist.

$\mathrm{He} / \mathrm{she}$ is passionate about science.

$\mathrm{He} / \mathrm{she}$ is curious and asks insightful and important questions.

$\mathrm{He} / \mathrm{she}$ knows the literature/research well.

$\mathrm{He} /$ she performs exceedingly at tests and exams.

His/her papers/essays are sententious and concise rather than long.

$\mathrm{He} / \mathrm{she}$ is popular among peers.

$\mathrm{He} /$ she regularly takes part in university-programs (cultural, sport, community, etc.) and he/she utilizes the opportunities of university.

$\mathrm{He} /$ she enquires about internships, study-tours, scholarships abroad.

His/her questions, comments, essays often pertain to other science-domain, to other topic.

After a failed exam, a negative critic, he/she works/learns more intensively and tries it harder again.

$\mathrm{He} / \mathrm{she}$ asks for help often.

Own option/opinion/observation:

26. Which methods/information are the most effective at identifying the talented students (the potential scientists)?

IQ test

Grade-Point-Average (GPA) in the end of the first semester. 
Making them write an essay about future-plans

Psychological questionnaires about motivation/curiosity

Making them solving practical problems in their chosen science-domain

Tasks specialized to their chosen science-domain

Questions about societal problems/dilemmas

Own option/opinion/observation:

27. How do you consider as important during the mentoring-process that we care not only about the professional development of the talented students, but also caring about the development of their personality, their future plans, and their attitudes toward the science?

1 - Unimportant

7 - essential

28. When a person applies for job in your institute, what are the most important features at the assessment of this applicant?

$\mathrm{CV}$

Motivation letter

Personal talk

Earlier scientific activity

Grade point average during studies

Whether he worked earlier at the institute

Others: 